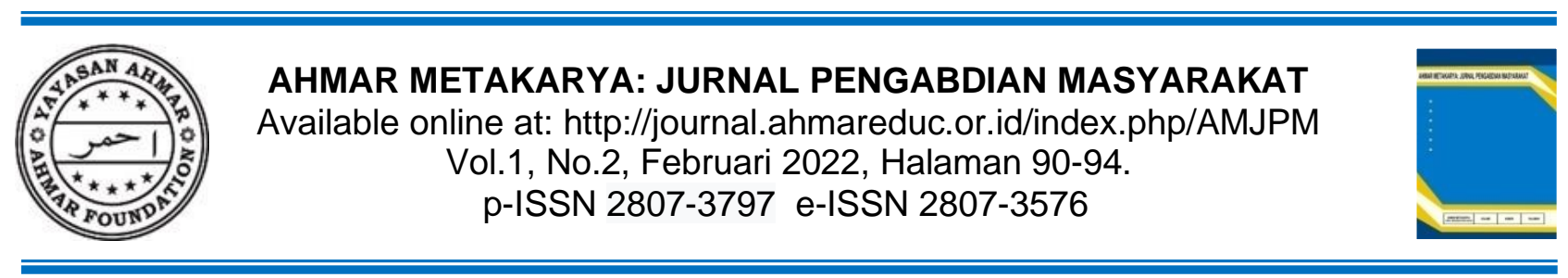

\title{
Edukasi Pencegahan Stunting dan Manajemen Pola Asuh dalam Pemenuhan Nutrisi pada Balita Melalui Pendekatan Terapi Komplementer
}

\section{Ni Ketut Ayu Mirayanti ${ }^{\star}$ Komang Sukraandini, Putu Gede Subhaktiyasa, Ni Ketut Citrawati, Sang Ayu Ketut Candrawati}

Program Studi Profesi Ners, STIKes Wira Medika Bali, Denpasar, Bali, Indonesia.

*E-mail: mirayantiniketutayu@gmail.com

Received: 9 Februari 2022

Accepted: 26 Februari 2022

Published: 28 Februari 2022

\begin{abstract}
Stunting is a chronic nutritional problem in toddlers which is characterized by a shorter height compared to children their age. According to the Data and Information Center of the Indonesian Ministry of Health (2018), said that the incidence of short toddlers or commonly referred to as stunting is one of the nutritional problems experienced by toddlers in the world today. The Bali Provincial Government Health Office Profile report (2018) that the percentage of short toddlers is quite high compared to the percentage of underweight and underweight toddlers, with the highest percentage of short toddlers being in the Bangli Health Center area of $44 \%$ of toddlers whose height was measured. The purpose of community service is to increase the knowledge and skills of mothers with toddlers in Stunting Prevention and Parenting Management in fulfilling nutrition for toddlers through complementary therapeutic approaches in Banjar Tegal Linggah, Songan A Kintamani Bangli Village, the method used is to provide counseling, demonstration and screening. The results obtained are $65 \%$ of mothers with toddlers understand about Stunting Prevention and Parenting Management in fulfilling nutrition for toddlers. $98 \%$ of mothers with toddlers are able to do complementary therapy with acupressure or massage techniques to increase appetite in toddlers.
\end{abstract}

Keywords: Toddler, Stunting, Education, Complementary.

\begin{abstract}
Abstrak
Stunting adalah masalah gizi kronis pada balita yang ditandai dengan tinggi badan yang lebih pendek dibandingkan dengan anak seusianya. Menurut Pusat Data dan Informasi Kementerian Kesehatan menyampaikan bahwa Kejadian balita pendek atau biasa disebut dengan stunting merupakan salah satu masalah gizi yang dialami oleh balita di dunia saat ini. Laporan Profil Dinas Kesehatan Pemerintah Provinsi Bali ahwa presentase balita pendek cukup tinggi dibandingkan presentase balita gizi kurang dan kurus, dengan presentase balita pendek tertinggi adalah di wilayah puskesmas Bangli sebesar $44 \%$ dari balita yang diukur tinggi badannya. Tujuan pengabdian kepada masyarakat yaitu meningkatkan pengetahuan dan keterampilan ibu dengan balita dalam Pencegahan Stunting dan Manajemen Pola Asuh dalam pemenuhan nutrisi pada balita melalui pendekatan terapi komplementer di Banjar Tegal Linggah Desa Songan A Kintamani Bangli, Metode yang digunakan adalah dengan memberikan penyuluhan, demonstrasi dan skrining. Hasil yang di peroleh adalah $65 \%$ ibu dengan balita memahami tentang Pencegahan Stunting dan Manajemen Pola Asuh dalam pemenuhan nutrisi pada balita. $98 \%$ ibu dengan balita mampu melakukan terapi komplementer tehnik akupresure atau pijat untuk meningkatkan nafsu makan pada balita. Kegiatan pengabdian masyarakat ini diharapkan menjadi program kegiatan di posyandu balita.
\end{abstract}

Kata Kunci: Balita, Stunting, Edukasi, Komplementer. 
Mirayanti, N. K. A., Sukraandini, K., Subhaktiyasa, P. G., Citrawati, N. K., \& Chandrawati, S. A. K. (2022). Edukasi Pencegahan Stunting dan Manajemen Pola Asuh dalam Pemenuhan Nutrisi pada Balita Melalui Pendekatan Terapi Komplementer. Ahmar Metakarya: Jurnal Pengabdian Masyarakat, 1 (2), 90-94.

\section{A. PENDAHULUAN}

Sunting adalah keadaan status gizi yang diukur berdasarkan indeks panjang badan menurut umur $(\mathrm{PB} / \mathrm{U})$ atau tinggi badan menurut umur $(\mathrm{TB} / \mathrm{U})$ dengan z-score $<-2$ SD (Kementerian Kesehatan, R. I., 2011) Menurut Sutomo dan Anggraeni, (2010), Stunting dibentuk oleh growth faltering dan catcth up growth yang tidak memadai yang mencerminkan ketidakmampuan untuk mencapai pertumbuhan optimal, hal tersebut mengungkapkan bahwa kelompok balita yang lahir dengan berat badan normal dapat mengalami stunting bila pemenuhan kebutuhan selanjutnya tidak terpenuhi dengan baik (Kementerian Desa Pembangunan Daerah Tertinggal dan Transmigrasi, 2017; Kementerian Kesehatan Republik Indonesia, 2016). Balita adalah istilah umum bagi anak usia 1-3 tahun (batita) dan anak prasekolah (3-5 tahun). Periode ini merupakan periode yang memiliki resiko untuk memperoleh berbagai penyakit infeksi, masalah sosial, cidera dan gizi kurang maupun masalah pertumbuhan dan perkembangan. Menurut Kementrian Kesehatan, R. I., (2018) menyampaikan bahwa Kejadian balita pendek atau biasa disebut dengan stunting merupakan salah satu masalah gizi yang dialami oleh balita di dunia saat ini. Data prevalensi balita stunting yang dikumpulkan World Health Organization (WHO), Indonesia termasuk ke dalam negara ketiga dengan prevalensi tertinggi di regional Asia Tenggara/SouthEast Asia Regional (SEAR). Rata-rata prevalensi balita stunting di Indonesia tahun 2005-2017 adalah 36,4\%. Laporan Profil Puskesmas III Denpasar Utara Tahun 2016 bahwa presentase balita pendek cukup tinggi dibandingkan presentase balita gizi kurang dan kurus, dengan presentase balita pendek tertinggi adalah di wilayah puskesmas Bangli sebesar $44 \%$ dari balita yang diukur tinggi badannya (Pemerintah Denpasar Kota, 2016). Masalah stunting pada balita di Indonesia pada tahun 2018 mengalami penurunan yaitu mencapai $(30,8 \%)$ dibandingkan dengan tahun 2013 yaitu $(37,2 \%)$, dimana Provinsi yang menduduki angka stunting tertinggi yaitu Aceh $(37,9)$, dan yang terendah yaitu Daerah Istimewa Yogyakarta $(28,1 \%)$ kemudian diikuti oleh DKI Jakarta $(27,2 \%)$ (Kemenkes, R. I., 2018)

Pencegahan dan penanggulangan masalah tersebut harus didukung oleh pengetahuan seorang ibu tentang stunting. Jika ibu tidak memahami tentang stunting akan menyebabkan meningkatnya kejadian stunting di suatu wilayah. Penelitian Picaully dan Toy (2013) mengatakan bahwa determinan kejadian stunting adalah pendapatan keluarga, pengetahuan ibu, riwayat infeksi penyakit, riwayat imunisasi, asupan protein dan pendidikan ibu. Salah satu faktor determinan kejadian stunting pada anak di bawah lima tahun adalah pengetahuan ibu. Pengetahuan merupakan domain yang sangat penting untuk terbentuknya tindakan seseorang. Pengetahuan diperlukan sebagai dukungan dalam menumbuhkan rasa percaya diri maupun sikap dan perilaku setiap hari (Notoadmodjo 2005). Peranan ibu sebagai pengasuh utama anaknya sangat diperlukan mulai dari pembelian hingga penyajian makanan serta pemenuhan kebutuhan sehari-hari seorang anak. Jika sikap seorang ibu kurang baik akibatnya balita tidak akan terpenuhi kebutuhan untuk peningkatan pertumbuhan dan perkembangannya. Berdasarkan fenomena dan data yang telah diuraikan diatas, maka peneliti ingin mengetahui gambaran pengetahuan ibu dengan balita tentang Stunting ddiwilayah kerja Puskesmas Bangli. Berdasarkan fenomena diatas kami berminat untuk melakukan pengabdian masyarakat terkait dengan "Edukasi Pencegahan Stunting dan Manajemen Pola Asuh dalam pemenuhan nutrisi pada balita melalui pendekatan terapi komplementer di Banjar Tegal Linggah Desa Songan A Kintamani Bangli.

\section{B. METODE DAN PELAKSANAAN}

Kegiatan pengabdian masyarakat yang dilakukan adalah mengenai Edukasi Pencegahan Stunting Dan Manajemen Pola Asuh Dalam Pemenuhan Nutrisi Pada Balita Melalui Pendekatan Terapi Komplementer Di Banjar Tegal Linggah Desa Songan A Kintamani Bangli kegiatan ini dilakukan melalui beberapa tahapan untuk meningkatkan pemahaman dan keterampilan Pencegahan Stunting dan Manajemen Pola Asuh dalam pemenuhan nutrisi pada balita melalui pendekatan terapi komplementer di Banjar Tegal Linggah Desa Songan A Kintamani Bangli. Kegiatan ini dilaksanakan mulai tanggal 11 Januari 2022 sampai dengan 14 Januari 2022 mulai pukul 10.00 sampai dengan 16.00 wita mulai dari persiapan sampai dengan pelaksanaan inti 
kegiatan. Pertama, penulis dan tim melakukan koordinasi dengan puskesmas 5 bangli untuk mengetahui birokrasi permohonan ijin untuk melakukan pengabdian masyarakat. Kemudian diarahkan untuk melakukan penyuratan untuk perijinan ke dinas Kesehatan kabupaten bangli dengan tembusan ke Puskesmas kintamani 5 Bangli dan desa songan A kintamani bangli. Selanjutnya Bersama sama dengan petugas Kesehatan puskesmas, penulis dan tim melakukan koordinasi untuk menentukan tempat dan waktu pengabdian masyarakat, menyampaikan maksud dan tujuan kegiatan, dan juga memperkenalkan tim yang ikut serta dalam kegiatan yang di maksud. Kedua. Penulis dan tim memberikan penyuluhan Kesehatan mengenai Pencegahan Stunting dan Manajemen Pola Asuh dalam pemenuhan nutrisi pada balita melalui pendekatan terapi komplementer dan sekaligus demonstrasi akupresure pada balita untuk meningkatkan nafsu makan pada balita di Banjar Tegal Linggah Desa Songan A Kintamani Bangli. Keempat penulis dan tim melakukan screening mengenai usia, berat badan dan tinggi balita yang hadir di balai banjar yang di bantu oleh kader dan petugas Kesehatan dari puskesmas. Kelima, pemberian bingkisan makanan sehat, leaflet, paket masker, dan alat permainan edukasi. Kegiatan ini merupakan kegiatan yang berupaya untuk membantu dan berupaya meningkatkan pemahaman masyarakat terkait stunting.

\section{HASIL DAN PEMBAHASAN}

1. Penyuluhan kesehatan tentang Pencegahan Stunting dan Manajemen Pola Asuh dalam pemenuhan nutrisi pada balita melalui pendekatan terapi komplementer di Banjar Tegal Linggah Desa Songan A Kintamani Bangli.

Kegiatan ini dilaksanakan pada hari Kamis 13 Januari 2022 bertempat di balai banjar Tegal linggah desa Songan A Kintamani Bangli pada pukul 10.00 Wita sampai selesai dengan mematuhi protocol Kesehatan. Peserta yang hadir sejumlah 28 orang ibu dengan balita. Penyuluhan awal yang disampaikan yaitu mengenai pencegahan stunting dan manajemen pola asuh pemenuhan nutrisi pada balita serta simulasi terapi komplementer untuk meningkatkan nafsu makan pada balita. Dimana penulis menjadi penyuluh dan juga menyebarkan leaflet kepada ibu ibu dengan balita. Dari hasil yang di peroleh setelah penyuluhan bahwa $65 \%$ ibu dengan Balita mengatakan memahami tentang materi yang di sampaikan.

Banyak faktor yang mempengaruhi pengetahuan seseorang. Pendidikan merupakan faktor utama yang berperan dalam menambah informasi dan pengetahuan seseorang dan pada umumnya semakin tinggi pendidikan seseorang makin mudah menerima informasi (Notoadmodjo, 2003).

Tabel 1. Rata-Rata tingkat Pendidikan Ibu di wilayah desa Songan Kintamani Bangli.

\begin{tabular}{llr}
\hline No & Pendidikan & Mean \\
\hline 1 & Tidak sekolah & $34.52 \%$ \\
\hline 2 & Belum tamat SD & $14.84 \%$ \\
\hline 3 & Tamat SD & $29.11 \%$ \\
\hline 4 & SMP dan SMA & 18.53 \\
\hline
\end{tabular}

Sesuai data di wilayah desa Songan Kintamani bangli sebagian besar penduduknya berpendidikan pendidikannya adalah tidak sekolah 34.52\%, belum tamat SD $14.84 \%$ dan $29.11 \%$ tamat SD.

2. Screening mengenai usia balita, berat badan dan tinggi balita di Banjar Tegal Linggah Desa Songan A Kintamani Bangli.

Screening usia balita, berat badan dan tinggi badan balita dilakukan di hari kedua yaitu pada pada hari Jumat tanggal 14 januari 2022 bertempat di balai banjar tegal linggah desa songan $A$ kintamani bangle pukul 10.00 Wita sampai dengan selesai. Peserta yang hadir sama dengan hari sebelumnya yaitu 28 orang ibu dengan balita. Screening ini dilakukan oleh tim pengabdian masyarakat dibantu oleh petugas Kesehatan dan satu kader Kesehatan. hasil analisis diperoleh bahwa Sebagian besar balita adalah usia 4 tahun sebanyak 12 orang (40\%). 
Tabel 2. Rata-Rata tingkat Pendidikan Ibu di wilayah desa Songan Kintamani Bangli.

\begin{tabular}{llr}
\hline No & Item & Mean \\
\hline 1 & 4 tahun & $40 \%$ \\
\hline 2 & Tinggi badan & $90 \mathrm{~cm}$ \\
\hline 3 & Berat badan & $12.12 \mathrm{~kg}$ \\
\hline
\end{tabular}

Hasil analisis diperoleh bahwa Sebagian besar balita adalah usia 4 tahun sebanyak 12 orang $(40 \%)$. Tinggi badan balita rata rata adalah $90 \mathrm{~cm}$. Hasil analisis untuk berat badan sebagian besar di peroleh12.12 kg.

3. Pemberian paket makanan sehat, masker anak, leaflet dan paket permainan edukasi

Kegiatan pemberian paket masker, makanan sehat, leaflet diberikan kepada ibu dengan balita berjumlah 28 orang dilakukan di hari yang sama saat screening yaitu hari sabtu tanggal 15 Januari 2022 bertempat di balai banjar tegal linggah desa songan A kintamani bangli. Paket permainan edukasi di serahkan kepada pihak puskesmas Kintamani 5 Bangli.
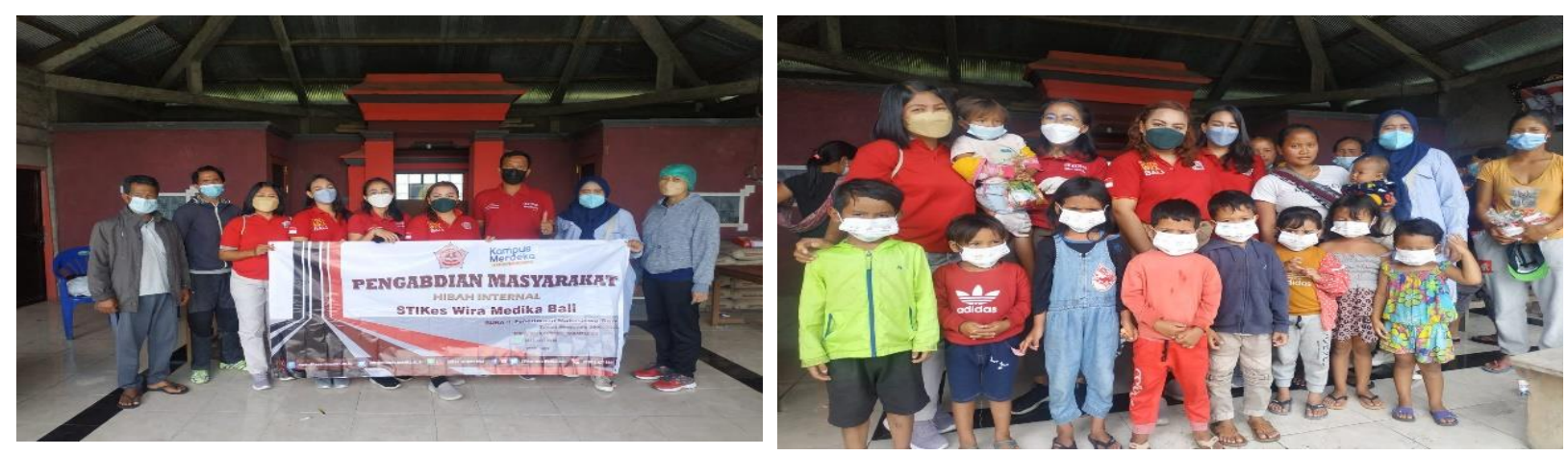

Gambar 1. Dokumentasi kegiatan edukasi manajemen stunting dan screening Kesehatan

\section{KESIMPULAN}

Kegiatan pengabdian masyarakat mengenai "Edukasi Pencegahan Stunting Dan Manajemen Pola Asuh Dalam Pemenuhan Nutrisi Pada Balita Melalui Pendekatan Terapi Komplementer" dengan memfokuskan tiga kegiatan yaitu (1) program penyuluhan Kesehatan mengenai manajemen stunting dan pijat akupresure untuk meningkatkan nutrisi pada balita didapatkan data $65 \%$ dari 28 ibu mengalami peningkatan pengetahuan; (2) screening Kesehatan untuk status nutrisi sebagian besar balita adalah usia 4 tahun sebanyak 12 orang (40\%). Tinggi badan balita rata rata adalah $90 \mathrm{~cm}$. Hasil analisis untuk berat badan sebagian besar di peroleh $12.12 \mathrm{~kg}$; (3) pemberian paket APE untuk mendukung program di posyandu.

\section{UCAPAN TERIMA KASIH}

Ucapan terima kasih yang sebesar-besarnya kami sampaikan kepada Kepala Dinas Kesehatan Kabupaten Bangli dan kepala puskesmas Kintamani 5 Bangli, yang telah memberikan izin dan dukungan terhadap pelaksanaan kegiatan. Kepala Dusun dan tim posyandu balita desa Songan A banjar Tegal Linggah kintamani, Bangli Bali. yang telah memberikan dukungan tenaga terhadap pelaksanaan kegiatan yang telah memberikan dukungan terhadap proses kegiatan dan fasilitas selama kegiatan. STIKes WIra Medika Bali yang telah memberikan dukungan dana melalui hibah institusi pengabdian masyarakat internal.

\section{DAFTAR PUSTAKA}

Kementerian Kesehatan, R. I. (2018). Hasil Utama Riskesdas 2018. Jakarta: Kementerian Kesehatan Republik Indonesia.

Kementerian Desa Pembangunan Daerah Tertinggal dan Transmigrasi. (2017). Buku saku desa dalam penanganan stunting. Kementerian Desa Pembangunan Daerah Tertinggal dan Transmigrasi 
Kementerian Kesehatan Republik Indonesia. (2016). Situasi Balita Pendek. ACM SIGAPL APL Quote Quad, 29(2), 63-76. https://doi.org/10.1145/379277.312726

Kementerian Kesehatan, R. I. (2011). Keputusan Kementrian Kesehatan RI tentang Standart Antropometri Penilaian Status Gizi Anak. Jakarta: Kementerian Kesehatan Republik Indonesia.

Pemerintah Denpasar Kota. (2016). Laporan Profil Puskesmas III Denpasar Utara Tahun 2016. Denpasar: Pemerintah Denpasar Kota.

Notoatmodjo, S. (2005). Metodologi Penelitian Kesehatan (Edisi Revisi). Jakarta : PT. Rineka Cipta

Notoatmodjo, S. (2003). Pendidikan dan Perilaku Kesehatan. Jakarta : PT. Rineka Cipta.

Picauly, I., \& Toy, S. M. (2013). Analisis determinan dan pengaruh stunting terhadap prestasi belajar anak sekolah di Kupang dan Sumba Timur, NTT. Jurnal gizi dan pangan, 8(1), 55-62.

Pusat data dan Informasi kementerian Kesehatan, R. I., (2018). Situasi Balita Pendek (Stunting) di Indonesia. Jakarta: Kementerian Kesehatan Republik Indonesia.

Sutomo, B \& Anggraini, D. Y. (2010). Menu Sehat Alami Untuk Balita \& Batita. Jakarta: PT. Agromedia Pustaka. 